\title{
GLOBALIZATION AND DEREGULATION OF LEGAL SERVICES•
}

Nuno Garoupa, University of Illinois, ngaroupa@illinois.edu

\begin{abstract}
In a series of influential papers, Larry Ribstein (2010, 2011) delivered his vision about the future of the market of legal services, including legal education and the structure of law firms. In this paper, we review current trends at the global level and discuss the extent to which globalization of legal services has in fact promoted or induced deregulation.
\end{abstract}

\section{Introduction}

Globalization of legal services tends to be associated with more competition and therefore can be understood as a force of market deregulation. ${ }^{1}$ However, given the particular market structure, there is also pressure for more regulation to protect incumbent players and exclude foreign lawyers. Ribstein believed change was inevitable in the U.S. market for legal services as big law firms are under pressure to change practices, and believed legal education should be more business-oriented. The purpose of this paper is to assess the degree to which Ribstein's important insights can benefit from the variety of experiences outside of the United States.

For example, the European Commission, in particular the Directorate-General for Competition, has shown an interest in promoting competition in the market for legal services since the early

\footnotetext{
- I am immensely grateful to Frank Stephen for lengthy discussions about legal services and globalization. Hugo Acciarri, Jesús Alfaro, Amitai Aviram, Carlos Andres Delvasto Perdomo, Carlos Bacalao-Fleury, Michael Faure, Adriana García, Arushi Garg, Eleanor Gerasimchuk, Carlos Gómez Ligüerre, Fernando Gómez Pomar, Kanok Jullamon, Kil Won Lee, Rafael Mery, Antonio Nicita, Roberto Pardolesi, Jimmy Paredes, Mariana Pargendler, Niels Philipsen, Jairo Saddi, Hans-Bernd Schaefer, Robert Chang-hsien Tsai, Annie Ying Xue and the participants at the George Mason University Research Roundtable on Unlocking the Law, September 20-21, 2012 and at the George Mason University Conference on Unlocking the Law, November 9, 2012, Arlington, Virginia and the participants at the University of Alabama Law School seminar for providing very useful suggestions. Erin Cox and Roya H. Samarghandi provided excellent research assistance. The usual disclaimer applies.

${ }^{1}$ I understand "deregulation" to mean the process by which current regulations largely imposed by the profession itself are reduced in substance, thus opening up the market for legal services. At the same time, I use the term "reregulation" to mean statute changes that enhance directly or indirectly the interests of the incumbent lawyers, therefore restricting the market for legal services.
} 
2000s. ${ }^{2}$ Some countries such as the United Kingdom have taken this matter seriously. After a long review process, the British government has recently implemented a new regulatory set-up for legal services in order to foster competition, innovation, and consumer protection, as well as so-called accountable regulatory enforcement (under the Legal Services Act 2007; hereafter "LSA 2007"). These reforms were prepared by the Clementi Report (published in December 2004). It argued for alternative business structures (allowing non-lawyers to go into business with lawyers as well as non-lawyer ownership of law firms, including the possibility of public trading of shares in law firms; hereafter "ABSs"), an independent agency to deal with disciplinary complaints (rather than leaving it to self-regulation; currently performed by the Legal Ombudsman and the Office for Legal Complaints), and greater freedom for legal service providers to compete (under the supervision of the Legal Services Board, operational since 2010). The reform failed to suppress the distinction between solicitors and barristers, but the new alternative business structures could in the future further contribute to blur this distinction. ${ }^{3}$ It is probably too early for a full-fledged assessment of the impact of these legal reforms on the market for legal services in the United Kingdom, but the general sense seems to be that they have modernized the institutional framework in the right direction while having made the market more competitive just in time for the 2008 recession (unlike the United States, a point strongly emphasized by Ribstein). ${ }^{4}$

However, not all European countries have moved in the direction of deregulation. Until recently Spain had no bar exam. Law graduates simply needed to register with the local bar after completing their degree (of five years in the past, now four years due to the Bologna Agreements that created the European Higher Education Area; hereafter "EHEA"). The consequence is that Spain currently has one of the highest numbers of lawyers in per capita terms (slightly behind the

\footnotetext{
${ }^{2}$ See Garoupa (2008), Terry (2009), Philipsen (2010), and Stephen (2013) for an overview.

${ }^{3}$ See Bowles (1994) for the distinction and economic implications. Furthermore, the LSA 2007 did not reform the Queen's Counsel.

${ }^{4}$ See Terry (2009), Boon (2011), and Stephen (2013). Although the authors disagree on the relative merits of the LSA 2007, they all recognize an important impact in the market for legal services in England and Wales. Still, the LSA 2007 can only have significant effects in years to come given that the registration process for alternative business structures approval began in 2012.
} 
United States). ${ }^{5}$ However, a large proportion of these "lawyers" are actually not practicing law but are merely registered with the local bar. With the excuse that Spain was different from the other EU Member States, the Spanish government introduced a bar exam in 2006, effective from $2011 .^{6}$ At this stage, the passing rates for this exam are unknown, but it is possible to see the new bar exam being used to reduce entry to the profession under the pretense of improving quality. ${ }^{7}$ At minimum, it will delay entry into the market for legal services for another eighteen months.

Another example in the same path is Portugal. Law graduates are accepted for a training period at the end of which there is a (national) bar exam with a significantly high passing rate. Due to an expansion of legal education in the mid-1990s, the number of lawyers has increased considerably in the last decade or so, putting Portugal well above average in terms of the number of lawyers per capita within the European Union. As a consequence there has been pressure for more competition in a market traditionally characterized by strong cartelization and considerable rentseeking. The response from the national bar was simple: introduction of a new (national) bar exam to enter the training period. So far the passing rate has been less than ten percent. ${ }^{8}$ The solution was certainly welcomed by the incumbents. ${ }^{9}$

There is no doubt that Ribstein's insights are powerful and important to understand current trends in the U.S. market for legal services. At the same time, a quick glance around the world shows a wide variety of experiences and paths. All jurisdictions have been impacted by

\footnotetext{
${ }^{5}$ Generally see Atienza (2012).

${ }^{6}$ Apparently some less prestigious law schools were in the business of allowing foreigners (in particular, Italians) to get a degree in law as a way to bypass regulations in their home countries. Notice the new bar exam is not supposed to test legal knowledge but rather lawyering skills and court structure.

${ }^{7}$ For a while there was a discussion about the bar exam being regional (in particular, the possibility of distinct Catalan and Basque exams was considered). The Spanish authorities finally opted for a national exam.

${ }^{8}$ Deliberation 3333-A/2009 (Ordem dos Advogados). An initial decision by an administrative court declared the deliberation unlawful (March 2010) and later the Constitutional Court found it unconstitutional (January 2012). The Portuguese bar has promised to change the deliberation to comply with the judicial decisions while insisting that an entry exam is needed to assess legal knowledge.

${ }^{9}$ Unsurprisingly, the President of the bar was reelected by a large majority in recognition of his work.
} 
globalization in legal services. ${ }^{10}$ Not all deregulate. Many reregulate. Local markets for legal services around the world have contracted after 2008; however, these impacts have generated significantly different consequences. ${ }^{11}$ As we will show in this article, the American experience with globalization does not reflect a general trend even if we limit our focus to the developed economies. Consequently, some of the recommendations and predictions suggested by Ribstein have to be understood in a broader context. Clearly American law firms and American legal education cannot ignore globalization. In point of fact, as Ribstein suggests, it is either globalize or perish. ${ }^{12}$ Still, the other jurisdictions in this new wave of a globalized world are not statically waiting for the U.S. market for legal services to change. They have followed their own pathways. Naturally, we can question Ribstein's important contribution in the context of this diversity of experiences.

The impact and possibilities of globalization cannot be correctly assessed in the absence of understanding the market for legal services. There is no such thing as a single market for legal services. The market is highly segmented between personal and corporate submarkets (Hadfield, 2000). Such segmentation correlates significantly with litigation versus transactional lawyering. It is also geographically dispersed given the asymmetric location of business and market opportunities.

The relative weight of the two segments of the market varies across the world. The distinction between personal and corporate submarkets has been quite well-defined in the U.S. for a while. However, that is not the case in most markets for legal services around the world. In fact, a possible consequence of globalization in Europe, East Asia and Latin America has been the segmentation of the market for legal services and the emergence of a distinct corporate segment where U.S. law firms have operated quite successfully.

\footnotetext{
${ }^{10}$ See, for example, discussion by Terry (2005) making similar observations about legal ethics in lawyering. More recently, see Terry, Mark and Gordon (2012a) on globalization of the legal profession.

${ }^{11}$ Even in China, see Li and Liu (2012).

${ }^{12}$ For example, Wald (2012) is much less radical in his analysis of big law firms in the United States. Yet the author seems to assume that the decision whether or not to globalize is a prerogative of U.S. law firms independent of the rest of the world.
} 
We contend that globalization, rather than inducing deregulation of the market for legal services, has promoted segmentation outside of the United States. The segmentation between corporate and personal markets around the world initially helped the expansion of big Anglo-American law firms in foreign jurisdictions. Yet, as local law firms adapt, these big law firms now face stiffer competition.

At the same time, segmentation to a large extent deters deregulation. Personal markets are largely local and immune to globalization. Moreover, if local law firms are seriously excluded from the corporate market, they might resort to reregulation in the personal segment to further exclude foreign competition from areas where they could be challenged (such as certain types of profitable personal injury or class action). In corporate markets, big law firms can bypass regulations when needed and it is therefore unclear why they should waste resources on lobbying for deregulation that will not generate significant gains. Big Anglo-American law firms might be interested in selected deregulation in foreign jurisdictions so as to facilitate their business, but they do not generally enjoy a good enough position to force such change (precisely because they tend to lack strong local connections).

In Section II, we summarize the insights offered by Ribstein in his remarkable 2010 and 2011 articles and discuss the problems posed by globalization in the market for legal services. In Section III, we look at different jurisdictions and the way they have addressed these challenges. In Section IV, we discuss the implications for globalization and deregulation. In Section V, we conclude.

\section{Larry Ribstein's Theory of the Market for Legal Services and Globalization}

In The Death of Big Law, Ribstein explains why big U.S. law firms can no longer survive. His argument is that the structure of big law firms follows a traditional model based on "reputational bonding" where additional fees pay reputational gains. In fact, he already pointed out some of the problems with this "reputational bonding" model in a previous article. ${ }^{13}$ There, more than ten

\footnotetext{
${ }^{13}$ See Ribstein (1998), where the author discusses how law firm structure responds to agency costs.
} 
years ago, Ribstein argued that the old "reputational bonding" model could not deal effectively with agency costs which, in time, would become unsustainable from a business perspective. In the most recent paper, Ribstein made the fundamental observation that the old model is simply misadjusted to current market needs. More controversially, he argued that the "reputational bonding" model was economically unviable well before the 2008 crisis. In fact, the breakdown of the traditional model is explained by many reasons that have overlapped in recent times and, to a large extent, unraveled after 2008. As a consequence, Ribstein proposed a new business model for big law firms which requires deep and profound changes in the internal structure (partial integration, outside equity capital, more research and development) and in the regulatory environment (where the English LSA 2007 is explicitly mentioned as an example of improved regulation).

One reason presented by Ribstein for The Death of Big Law is the rise of in-house counsel (which clearly reduces asymmetry of information and therefore the need for external legal services). Significant investment in in-house counseling has been made profitable for large corporations and big business by the expensive legal fees charged by the largest law firms. Internal legal services are expensive since large corporations have no comparative advantage in such technology. However, as legal fees for outside counsel increase significantly, a critical threshold has been achieved at which it is actually more cost-effective to use internal legal services.

Other reasons for The Death of Big Law mentioned by Ribstein include changing market conditions (such as shifts in clientele type or priorities, a continuous decline in hourly billing, and a remarkable deprofessionalization of law practice), varying internal conditions (problems with economies of scale, increasing partner-associate ratios, and limited liability) and increasing of global competition. It is the latter we will focus on in this article.

Global competition is described by Ribstein as an important element to explain The Death of Big Law at several levels. First, on the supply side of legal services, in the last few decades or so global corporations could simply opt for cheaper law firms in foreign markets where they provide similar legal quality with equally skilled legal human capital. For example, Ribstein 
mentioned non-American law firms practicing in financial centers such as London, Singapore and Hong-Kong. He added New York since important foreign law firms are likely to locate there in order to attract American business. Furthermore, according to Ribstein, this global effect has been seriously enhanced by Sarbanes-Oxley (since regulation of foreign companies cross-listing in U.S. markets has been streamlined).

Second, Ribstein suggested that possible outsourcing of legal services to India and other places with low labor costs inevitably financially undermines big U.S. law firms. At the moment, outsourcing might be limited to the commodity end of legal work (because it is easier to standardize and import) and to cheap jurisdictions with English language and a common law tradition (such as India and, less so, South Africa). However, an expansion of this global effect cannot be excluded at the moment; this is a trend that a big law firm simply cannot ignore.

Finally, foreign practices are now able to compete more vigorously. The traditional advantage of U.S. big law practices, which successfully dominated some segments of legal markets in Europe and in East Asia for fifteen years, is now outdated. Foreign law firms have imported the U.S. model and improved it. Such developments are simultaneously a response to local legal knowledge as well as a better or more adequate regulatory setup.

In The Death of Big Law, Ribstein understood the tremendous impact globalization has had on the U.S. market for legal services. He recognized that big law firms were able to acquire a significant market share abroad and used it to hide a losing "reputational bonding" model back home. In the last five-to-ten years, U.S. leadership has been seriously undermined which has changed the nature of globalization for big law firms. Consequently, Ribstein argued that big U.S. law firms have to change their structure and behavior in this new stage of globalization. At the same time, he argued that the regulatory setup has to change if big U.S. law firms are to capitalize on their knowledge and practices around the world.

In a later paper, Ribstein added legal education as the third pillar of change alongside the business structure of big law firms and the regulatory setup. In fact, in Legal Education for the Twenty-First Century, the author argued that American legal education needs to be more 
business-oriented (but not necessarily "practical" in the way others understand it; theory matters in his view) and ready to face globalization (he suggested a model for global legal education). Ribstein was not optimistic about American law schools understanding the challenges and possibilities posed by globalization, but he adamantly recommended significant reform.

There is no doubt that globalization has generated competition between big U.S. law firms and foreign law firms. This competition was probably initially sharper in financial centers outside of the United States, and later in New York itself. Still, it seems that in order to understand the impact of globalization in the market for legal services, we need to consider that the mechanism explaining this process was more the relocation of financial activities than the search for better and more cost-effective legal services in other jurisdictions. Many U.S. companies have developed significant business interests in Europe, East Asia and South America in the last twenty years. London, Frankfurt, Hong-Kong and Singapore have emerged as attractive global financial centers. When big American corporations expanded in these markets, they inevitably brought their legal advisers, mainly big American law firms. Big American law firms quickly realized they needed to expand their activities in these new markets. Big law firms were not looking at Brazil or Taiwan to enter the local legal markets. Rather, U.S. (and later European) companies doing business introduced American (and later European) legal services there. ${ }^{14}$

As Ribstein correctly pointed out, big U.S. law firms had a better or superior production technology but, as added by Stephen (2013), they lacked the adequate local knowledge. ${ }^{15}$ Consequently, two things happened. First, the progressive Americanization of many processes and client service activities, that is, legal services that were largely independent of local law, easily transplanted from U.S. legal markets and were better than the local offer back then. Second, at the same time, joint ventures with local law firms were created in order to address local knowledge and information inadequacies. Eventually, with time, these local law firms have improved their technology and, to a certain extent, have now less need for U.S. legal human capital in foreign markets.

\footnotetext{
${ }^{14}$ Including U.K. law firms in Australia and Asia and Spanish law firms in Latin America.

${ }^{15}$ By local knowledge I mean local law, local language and, more importantly, local reputation and connections. Anglo-American law firms can easily address local law and local language by hiring directly local human capital, but they are at a disadvantage when it comes to local reputation and connections.
} 
It is easy to understand that multijurisdictional law firms might be able to more efficiently combine American technology advantages with local knowledge. Nevertheless, they face serious impediments because legal activities are subject to licensing by individual jurisdictions. Moreover, these regulations tend to favor local law firms and not multijurisdictional law firms. For example, many jurisdictions insist on denomination in the local language which clearly raises the costs for foreign law firms. Joint ventures with local law firms were, in the context of regulatory restrictions, the best response.

The distinction between personal and corporate segments seems to matter in this context (Hadfield, 2000). While such distinction has existed in the United States and is by now mature, it is relatively more recent around the world.

Similarly, litigation financing varies across the world. It is true that big U.S. law firms are fundamentally transactional and rely on international commercial arbitration, therefore the relevance of local courts to their business is reduced. Still, some significant segments of legal markets are naturally less exposed to globalization because of these variations in litigation financing. Legal aid, court-imposed fees, or third-party insurance are different ways of organizing access to courts. Some of these forms can be easily captured by local interests and they can be difficult to overcome by foreign law firms. Coupled with regulation of legal services, they fundamentally shield the personal segment of the market from effective globalization.

Big law firms are exposed to two types of important clients: corporations and governments. Corporations tend to be global clients. Governments are primarily local clients. When the latter generates more revenue than the former in legal fees, we have closed markets that cannot be easily penetrated by foreign law firms. In my view, this explains a significant contrast between the U.K. market, where corporate clients are overwhelming, and Southern Europe, where governmental and government-related clients play an important role. ${ }^{16}$

\footnotetext{
${ }^{16}$ Governments tend to rely on big Anglo-American law firms for international litigation or sovereign bond issuing. Here I focus on governments as local clients in reference, for example but not only, to administrative litigation or drafting legislation. The reality of course varies from country to country largely as a function of existing government
} 
Summing-up, the corporate segment is the one primarily exposed to globalization. ${ }^{17}$ More importantly, we need to note that Ribstein focused primarily on big law firms operating in the corporate segment around the world. In other words, his analysis of globalization applies to a particular segment of the market. Still, the role and structure of the corporate segment of the market for legal services varies across jurisdictions. Hence, generalizations from the U.S. experience are risky and likely to be misleading.

\section{The Rest of the World}

For most European jurisdictions, as we have seen, the role of European law has been vital in promoting competition in the market for legal services. First, Directive 2005/36/EC on professional qualifications has consolidated previous directives and has promoted further integration of professional markets, thus enhancing competition in the traditionally and still largely protected European markets for legal services. ${ }^{18}$

Second, case law has been significant since the early 2000s. In particular, the Morgenbesser ${ }^{19}$ case defended the principle that free establishment applies even to those who have not completed their legal education (in this case, training) in their home state, and the Koller ${ }^{20}$ case decided that a legal degree completed in a different country (in the particular case, Spain) cannot preclude access to the profession in the home country (in this particular case, Austria) even when "completion" follows different standards (in Spain, it did not require training at that time). ${ }^{21}$

\footnotetext{
lawyers (for example, Abogados del Estado in Spain) and the extension of government influence in the economy (for example, state-owned companies).

${ }^{17}$ In fact, Sechooler (2009) criticizes the globalization of legal services by noting the concentration on a limited number of Anglo-American law firms as the most immediate consequence.

${ }^{18}$ The extent to which the directive has been successful is less obvious and begs further analysis that the European Commission is likely to publish soon.

${ }^{19}$ Case C-313/01, Christine Morgenbesser v. Consiglio Dell'Ordine Degli Avvocati di Genova, 2003 E.C.R. I13467.

${ }^{20}$ Case C-118/09, Koller, 2010 E.C.R. I-0000.
} 
Previously, in the Wouters ${ }^{22}$ case, traditional arrangements such as prohibition of multidisciplinary partnerships were challenged (in the Netherlands) and, in the Arduino ${ }^{23}$ case, fee limitations were questioned (in Italy). In both, the European Court of Justice was reluctant to override such practices but stated that lawyering was not per se excluded from antitrust principles. $^{24}$

Furthermore, the Council of Bars and Law Societies of Europe (CCBE) has been trying to regulate some minimum standards in terms of training and ethics across the European Union. ${ }^{25}$ Still, not surprisingly, it has opposed extensive deregulation and it has criticized the general policy of the European Commission in regard to forcing competition in lawyering. ${ }^{26}$

Some jurisdictions have taken longer than others, but European law has forced the more traditional jurisdictions to open up their markets for legal services. It is possible that some of the European jurisdictions comply with this trend more de jure than de facto, using local practices and networks to undermine formal law. Still, the general pattern is undeniable. There is more competition in the lawyering business in Europe now than twenty years ago.

Notwithstanding, the U.K. is a notable exception. We can find significant reforms in the legal profession during the 1980s under the Thatcher government, with Lord Mackay as Lord Chancellor (Abel, 2003). These reforms were deregulatory in nature and were broadly opposed by the legal profession (Abel, 2003; Stephen, 2013). However, a deep division between solicitors and barristers alongside economic changes in the 1990s weakened any solid and potentially

${ }^{21}$ Lonbay (2012) summarizes how European law has shaped deregulation concerning the market of legal services in Europe. In many jurisdictions, European law might even be disguised as national law.

${ }^{22}$ Case C-309/99, Wouters v. Algemene Raad van de Nederlandse Orde van Advocaten (NOVA), 2002 E.C.R. I1577.

${ }^{23}$ Case C-35/99 Arduino, 2002 E.C.R. I-1529.

${ }^{24}$ See Garoupa (2008) for a discussion of case law in Europe, in particular, the implications of the Wouters case. Another important case is the Engeleer decision in the Netherlands (2000), where the Dutch competition authority decided that the prohibition of contingency fees violates competition law. There were later developments, but the prohibition still holds today.

${ }^{25}$ As recognized by Terry (2009) and Lonbay (2012).

${ }^{26}$ See Garoupa (2008). 
effective opposition. By the time of the Clementi reforms (report issued by 2004 and legislation approved by 2007), there was no strong professional opposition able to halt them (even if lawyers were still dominant in the legislative branch). Furthermore, the general shortcomings of other significant reforms such as legal aid and court services (Legal Aid Act 1988, Courts and Legal Services Act 1990, Courts Act 2003) convinced part of the profession that the new LSA 2007 was indeed needed. In fact, most of the controversy was around the timing of implementation, and not the substance of the new legislation (Stephen, 2013). ${ }^{27}$

There is no question that the LSA 2007 changed the fundamental structure of the market for legal services by reinforcing competitive provisions within self-regulation. However, the LSA 2007 develops a framework based on two distinct regulatory forces. ${ }^{28}$ Its foundation goes back to the system of regulatory competition introduced by the Administration of Justice Act 1985 and the Courts and Legal Services Act 1990. Under these provisions, the market for legal services was regulated by the Solicitors Regulatory Authority, the Bar Standards Board and the Council for Licensed Conveyancers. However, competition was largely absent in this framework. The LSA 2007 added a new body, the Legal Services Board, which is now supervising the regulatory activity under an explicit obligation to foster and conduce competition in the market for legal service.

Another interesting jurisdiction is Scotland, due to its proximity to England and Wales and the hybrid nature of its legal system. ${ }^{29}$ More competition was promoted by the Legal Services (Scotland) Act 2010 (hereafter "LSSA 2010"). However, ABSs under the LSSA 2010 are different from those under the English LSA 2007 since only 49\% of an ABS may be owned by non-lawyers. Notwithstanding, regulatory competition in Scotland has taken similar paths to that of England and Wales.

\footnotetext{
${ }^{27}$ Boon (2011) provides a critical overview of the LSA 2007, in particular how regulatory competition hinders traditional legal professionalism.

${ }^{28}$ Following Stephen (2013).

${ }^{29}$ We follow Stephen's (2013) description of Scotland here.
} 
Therefore, we can easily say that the U.K. has now a much more powerful setup for regulatory competition than the U.S., as certainly noted by Ribstein. Hadfield (2008) and Ribstein blame to a large extent (and, in my own view, correctly) the American Bar Association for the lack of regulatory competition and, consequently, innovation in legal practice. Strict controls imposed on legal services, a largely homogeneous legal education and severe organizational limitations have produced uniform educational and practical backgrounds that undermine innovation. As noted by Stephen (2013), clearly the LSA 2007 inspires a different setup by liberalizing legal services and allowing new business forms for lawyers in England and Wales (as does the LSSA 2010 in Scotland).

However, as we will explain later, the LSA 2007 does not really address or change the business setup for the big law firms, a point overlooked by Ribstein. In other words, the English LSA 2007 is in the spirit of deregulation defended by Ribstein. Still, the exact content of this legislation does not really directly address Ribstein's concerns with American big law firms as we will see.

Israel has recently amended its laws to allow foreign lawyers to practice foreign law in Israel. ${ }^{30}$ It is likely that Israel should be somewhat more open to lowering barriers to entry of American law firms than other countries. The economic and political proximity with the United States should play a role (not least, many areas of Israeli law and legal education have been substantively influenced by American law and legal education). We can also easily suppose that most foreign lawyers who move to Israel are Jewish, and thus are not likely to be perceived by the Israeli incumbent lawyers as entirely "foreign." Therefore, it is possible to say that Israel has been impacted by globalization in ways that Ribstein expected but to a large extent it is a particular context. ${ }^{31}$

\footnotetext{
${ }^{30}$ See information here, http://www.israelbar.org.il/english_inner.asp?pgId=124241\&catId=4389 (last checked September 1, 2012).

${ }^{31}$ For a general discussion, see http://www.law.harvard.edu/programs/plp/pdf/Israeli_Legal_Profession.pdf (last checked September 1, 2012).
} 
Another interesting case is Australia. It has followed the deregulation path in the last decade or so. ${ }^{32}$ Yet while Anglo-American law firms have been successful in expanding their business globally, Australian law firms have been much less effective. This observation has attracted attention by legal scholars who have discussed Australian law firms and why they seem to be less successful than Anglo-American law firms. ${ }^{33}$ They note that globalization has less impacted the Australian market while a few elite law firms have tried to expand business into the Asian market. These Australian law firms tend to replicate the technology of Anglo-American law firms which obviously does not make them significantly more competitive elsewhere. ${ }^{34}$

In Europe, while the U.K. embarked in serious deregulation, there has been many jurisdictions where the entrenched profession has been very successful in reregulating (we already have offered Spain and Portugal as examples). More concretely, few jurisdictions within the European Union have adopted the deregulation mode like the U.K. It is easy to see in Southern Europe how easily lawyers captured the legislator and the production of legislation to kill any attempt of serious deregulation. In many other cases, as noted by Stephen (2008) with respect to Germany and France, the support for deregulation actually came from courts deciding against lawyers' regulatory bodies.

Lawyering in Germany is traditionally regulated by statute. ${ }^{35}$ Although such legislation has largely been immune to competition law, courts have played an important role (not least because disciplinary action can be exercised by the bar and by the courts). A significant reform was introduced by the Professional Regulation for Lawyers ${ }^{36}$ in 1997; it accepted the

\footnotetext{
${ }^{32}$ See discussion by Terry, Mark and Gordon (2012b). In particular, notice the Legal Profession Act 2006 which is more limited than the LSA 2007 in terms of reforming regulation, see http://www.austlii.edu.au/au/legis/act/consol_act/lpa2006179/.

${ }^{33}$ See Pinnington and Gray (2007).

${ }^{34}$ In fact, the Australian legal profession might suffer from a brain drain phenomenon to the extent that U.S. and U.K. law firms seem more attractive to the elite lawyers. There is no bar exam, and it has gradually become less arduous to be admitted to practice. Yet the best and brightest law graduates in Australia seek to take up places in top American and European law firms.

${ }^{35}$ See Stephen (2008). We follow closely his description of German legal markets.

${ }^{36}$ Berufsordnung für Rechtsanwälte (BORA) enacted by the legal profession. The most important federal statute is Deutsches Richtergesetz (DRiG) that demands that every lawyer has to pass the official examinations for the
} 
professionalization of lawyering rather than following the more traditional model of lawyers as a formal body of the justice system. This had important implications for advertising, professional ethics, territorial limitations and, in time, legal fees. We should also recognize the active role of the German Constitutional Court in promoting deregulation by a series of decisions taken after $1987 .{ }^{37}$ They impacted advertising, employment of lawyers by non-lawyers, fee arrangements, professional indemnity insurance and new forms of partnerships. German law firms were traditionally small (less than twenty lawyers), as is typical in Europe, but expanded a lot in the late 1990s as a consequence of mergers with Anglo-American law firms. Legal scholars have reported how the deregulatory and pro-competitive developments have taken place against the expressed feelings of the German legal profession. ${ }^{38}$

The particularly interesting case of British law firms in Germany has been studied in detail by Stephen (2002). The author argues that Anglo-American law firms have a better production technology (reflecting a more competitive market for legal services in the U.K. than in Germany) described as a more corporate-like business model. However, they lacked the local specific knowledge. Such an asset was an advantage for German law firms. Only mergers between Anglo-American firms with better technology and German firms with more specific knowledge could internalize this conflict. At the same time, due to prevalent German regulation of lawyering (which allowed for multidisciplinary practices), international accounting and consulting firms promoted mergers with German law firms and seized a significant market share (mainly in the corporate segment of legal services). In fact, a decade later, Wenzler and Kwietniewska (2012) confirm that seven out of the ten largest law firms bear Anglo-American names but their legal practice is mainly German (both in substantive law and in local courts). There is definitely an international flavor in Frankfurt, Hamburg or Berlin but mainly focused on German legal practice.

judiciary, the so-called "two state exams". Further details are regulated by each Länder with the Juristenausbildungsordnung (JAO). The federal statute that regulates legal practice is the Bundesrechtsanwaltsordnung (BRAO). Traditionally, Germany was one of the most heavily constrained legal markets. See, more generally, Brunnee (1992), Klein (1993), and Ostertag (1993).

${ }^{37}$ A more detailed discussion is available by Stephen (2013).

${ }^{38}$ See Stephen (2013). 
Although regulation of lawyering in France has been fundamentally statutory, the coexistence of multiple actors in the market for legal services was actually regulated in a significantly decentralized arrangement. ${ }^{39}$ Traditionally, avocats had the exclusive right to plea before courts. At the same time, there were avoués (mainly the equivalent to the British solicitors), notaires and agréés (in fact, non-lawyers with plea rights before commercial courts). Due to the lack of strict regulation applied to agréés, it has been observed they effectively evolved into conseils juridiques. ${ }^{40}$ A significant reform took place in 1971. Avocats, avoués and agréés were merged in a single profession of avocat. ${ }^{41}$ The avocats exercising in the higher courts kept their monopoly (avocats au Conseil d'Etat et à la Cour de Cassation). Further changes in the 1990s promoted the approximation of avocats and conseils juridiques which according to Stephen (2008) aimed at cartelization and less competition in the French market for legal services. Most of the actual segmentation is now merely geographic while a national body of local bars (created in 1990) has been seeking to impose standardization.

As with most members of the European Union, training and regulation of lawyering in France have been profoundly affected by European law. ${ }^{42}$ However, enforcement is still done by French courts and largely subject to the nature of French law. Therefore, globalization in France has been significantly tempered by local practice. Furthermore, international law firms in Paris have been hit harder by the crisis than traditional smaller local firms. ${ }^{43}$ Bilingual training and legal practice in the French environment has been difficult; bijuralism training has been even more problematic. $^{44}$

\footnotetext{
${ }^{39}$ Reporting on France, Stephen (2008) recognizes the recent trends.

${ }^{40}$ See Stephen (2013).

${ }^{41}$ A similar reform took place in Belgium with the introduction of a new code of civil procedure (1970).

${ }^{42}$ As recognized by Du Marais (2012).

${ }^{43}$ Du Marais (2012), at 457.

${ }^{44}$ However, as Du Marais (2012) remarks, there are basically none of these in the United States.
} 
Stephen (2008) identifies two trends in regulatory action in French lawyering. First, the effort to limit or exclude multidisciplinary partnerships. Although initially successful, it got in trouble with the courts and the Cour de Cassation decided that some of the rules were against the law (by holding that only a statute could determine the extent to which ethics can be mandatory). Second, the pressure to exclude Anglo-American law firms mainly from the Paris market. The main goal was to protect market shares and avoid the adulteration of French practices by the influence of Anglo-American production technology. Such policy has largely failed in the face of European law.

Italian governments have made an effort to deregulate the local market for legal services. Innovations include the reform of traineeship (limiting the training period to eighteen months and the possibility of doing it while at law school) and the abolition of the tariffe (traditionally predetermined by the National Forensic Council with the Ministry of Justice). They were fiercely opposed by the legal profession and largely failed.

Spain has been previously indicated as the paramount example of reregulation. In fact, the statutory framework in Spain has been changed recently. Law 34/2006 from October $30^{\text {th }}$ and Real Decreto $775 / 2011$ from June $3^{\text {rd }}$ impose a requirement for an undergraduate and master degree in law for admission in the profession as well as an internship requirement and a bar exam. These statutory reforms are a consequence of the Bologna European Higher Education Area (EHEA) and free establishment within the European Union. ${ }^{45}$ They were particularly welcomed by the incumbent lawyers. ${ }^{46}$

The Spanish trend of further regulation operates in a market that has been quite exposed to globalization in its own way. The two largest law firms in Europe by the 2000s were actually Spanish (Garrigues and Cuatrecasas), and not British or American. ${ }^{47}$ The big law firms in

\footnotetext{
${ }^{45}$ The argument is suggested by Atienza (2012).

${ }^{46}$ The President of the Catalan bar (Colegio de Abogados de Barcelona) is reported as saying "We have been demanding this for the last one hundred years," http://www.aprendemas.com/Noticias/html/N8806_F06072011.html (last checked September 1, 2012).

${ }^{47}$ See Atienza (2012).
} 
Madrid and in Barcelona expanded their business as Spanish companies and banks internationalized their activity (Telefonica, Banco Santader, Repsol and Ferrovial). In fact, the Spanish legal market has expanded, driven mainly by external demand (mostly from Latin America) and not so much by local clients. ${ }^{48}$

Still Spain is not unique in its reregulation path. Finland has been recognized as an example of a jurisdiction with a pro-market regulatory setup. ${ }^{49}$ Essentially, one can say that legal practice in civil litigation is largely deregulated. Anyone with the appropriate law degree (within the European Higher Education Area, a master degree) is a lawyer (lakimes), both for the purpose of legal advice and legal representation in civil litigation. Notwithstanding, only those who are members of the Finnish bar can take criminal representation and provide general legal services. ${ }^{50}$ They are advocates (asianjaja). Still, recent legislation requires lawyers to train under the supervision of the bar before they can intervene in civil litigation. As correctly remarked by legal scholars, the Finnish system is reregulating, although within the boundaries of European law on the matter. ${ }^{51}$

It is not only Europe that is changing, as Asia has also seen important reforms. The traditional narrative has been that Asian jurisdictions have fewer lawyers than in the West because they are much less litigious societies; they simply do not need lawyers! Recent evidence has suggested the causation is probably reversed, in that there are not enough lawyers to provide services to all potential litigants. $^{52}$

\footnotetext{
${ }^{48} \mathrm{Id}$.

${ }^{49}$ See Stephen (2008).

${ }^{50}$ Id.

${ }^{51}$ Id.

${ }^{52}$ A good summary of the discussion and new evidence is provided by Ginsburg and Hoetker $(2006,2009)$.
} 
Legal markets in East Asia were largely kept closed by excluding foreign law firms and imposing a significantly low passing rate for bar exams (traditionally less than ten percent). ${ }^{53}$ In this context, Japan and South Korea have enacted important legal reforms to modernize their legal practice and make it more competitive in the last ten years (Japan in 2004 and South Korea in 2009). ${ }^{54}$ Quite remarkably, they have been inspired by the U.S. model of legal education (which, for example, has always been the case in the Philippines which is hardly surprising given the American influence there ${ }^{55}$ ). The most immediate consequence has been the notable increase in passing rates on the Japanese and Korean bar exams, still low for U.S. standards (below fifty percent), but clearly above the traditional figures. ${ }^{56}$ The transformation of the law degree from undergraduate to postgraduate (similar to a J.D. program) has been less far-reaching than expected, since the undergraduate degrees were not fully eliminated. ${ }^{57}$

Taiwan and Hong Kong have been changing at a slower pace. The political context (a process of democratization) has been fundamentally influenced by lawyers, but the changes in the market for legal services have been less remarkable than in Japan and Korea. ${ }^{58}$ Taiwan is the Asian jurisdiction with the most law professors educated in the United States (although still a minority). ${ }^{59}$ The Hong Kongese legal profession has been shaped by the British. Its vibrant

\footnotetext{
${ }^{53}$ See, for example, Schumman (2006) who mentions the Japanese bar passing rate being less than three percent in the 1980s and 1990s.

${ }^{54}$ For a general discussion of the new rosukuru model in Japan, see Maxeiner and Yamanaka (2004) and Schumman (2006). Different perspectives are presented by Riles and Uchida (2009) and Ramseyer (2011). On South Korea, see Jeong (2010) and references therein.

${ }^{55}$ See Dezalay and Garth (2010), at chapter six.

${ }^{56}$ See Matsui (2012) on the new bar examination in Japan, at 19-20. The numbers concerning passing rates seem to vary between thirty and forty-six percent. As to South Korea, the target passing rate announced by the Ministry of Justice was seventy-five percent. However, eighty-seven percent of the candidates passed in 2012. The old bar exam (for those under the previous system) is expected to remain until 2017.

${ }^{57}$ A point discussed by Ramseyer (2011) and Matsui (2012).

${ }^{58}$ The extent to which legal education in Taiwan should follow the reforms in Japan and Korea has been intensively debated. In fact, the Taiwanese government promoted in 2005 to 2007 a reform effort inspired by the Japanese and Korean models that largely failed due to strong opposition among legal academics. New rules for judicial and bar exams were introduced in 2011. The bar passing rate is now up from around ten percent to around thirty-three percent; see Chen (2012), at 59-60. Some big U.S. law firms have entered the local market recently mainly through joint ventures with Taiwanese law firms. See also Chang (2009) and Michelson (2012).

${ }^{59}$ See Hupper (2008).
} 
market and strategic location within Greater China have attracted the attention of the big law firms.

Thailand can also be seen in this context. The last amendment to the regulatory setup for lawyers dates from 1985 and it can hardly be regarded as deregulation. ${ }^{60}$ Passing rates at the licensing exam are typically low (usually less than fifty percent and even lower to pass the exam for barrister-at-law, a qualification needed to become a judge or a prosecutor). Clearly the entering standards have never been relaxed since the 1985 reform. At the same time, Anglo-American law firms in Thailand have not yet been influential in shaping the local market (with a more significant presence of British rather than American law firms). ${ }^{61}$

Mainland China is a different story. For many political and historical reasons, the reform of the legal profession has not been a major priority. Passing rates on the Chinese bar are low (possibly below thirty percent). ${ }^{62}$ The big demand for legal services is fundamentally concentrated in Beijing and Shanghai. Legal education has expanded significantly since the early 1990s, but most commentators agree that quality is a serious problem. The market is heavily regulated by the government (which does not exclude the possibility of less strict informal practices), which considerably limits foreign law firms. ${ }^{63}$

Finally, a word about the Indian legal market is in order. ${ }^{64}$ It is still very closed with a few court cases addressing the presence of British law firms providing advice about foreign law. ${ }^{65}$ The

\footnotetext{
${ }^{60}$ See Sathitsuksomboon (2012) in reference to the Lawyers Act of 1985.

${ }^{61}$ See list of foreign law firms in Thailand at http://www.hg.org/attorneys/Thailand.html (last checked August 27, 2012).

${ }^{62}$ The passing rates have increased after the 2002 modernization of the bar exam (up from around seven percent in 2002 to around twenty-five percent after 2008). Low passing rates with expansion of legal education, limited corporate activity and local protectionism (targeting lawyers from a different Chinese region), in my view, explains the big Chinese demand for U.S. LL.M. degrees. However, the great number of Chinese LL.M.s in the last twenty years has crowded out the Asian market for legal services from the point of view of American lawyers abroad.

${ }^{63}$ See generally Philipsen (2010), Cohen (2012), Li and Liu (2012), and Zhao and Hu (2012).

${ }^{64}$ Dasgupta (2010) describes the Indian experience as changing slowly, following the U.K. model but very closed to globalization. Ballakrishen (2012) provides a similar skeptical assessment with a focus on Indian lawyers with foreign legal education.
} 
market for legal services in India promises a challenging opportunity for the future but, at the moment, it is largely untouched by recent global trends.

We cannot say we see a strong pattern of deregulation of legal services in East Asia and India. At best, most jurisdictions have been investing in improving the quality of their legal human capital. Entry controls traditionally were severe (they still are in mainland China), thus failing to create a competitive market (perhaps with the exception of Hong Kong). Recent reforms might change this pattern in the future but, at this stage, their impact is unclear. Local commentators are divided on the merits of these reforms. ${ }^{66}$

Latin America has also been exposed to globalization in the market for legal services, but the pattern of reform and deregulation is remarkably weak at the moment. ${ }^{67} \mathrm{~A}$ few Anglo-American law firms have shown interest in Latin America, generally in joint venture with local large law firms. ${ }^{68}$ Yet we cannot see any noteworthy movement of deregulation there. ${ }^{69}$

${ }^{65}$ AK Balaji v. Union of India [Madras High Court judgment on entry of foreign law firms in India, 2012] and Lawyers Collective v. BCI [High Court of Judicature at Bombay, 2010], although they go in opposite directions concerning the interpretation of litigious and non-litigious services under the Advocates Act 1961. Both are currently standing appeal at the Supreme Court of India.

${ }^{66}$ See Riles and Uchida (2009) and Ramseyer (2011).

${ }^{67}$ For a general view, see Dezalay and Garth (2002). Furthermore, Montoya (2010) does not provide an optimistic view of legal education reform in Latin America. Significant regulation and limited private initiative tend to prevail. In the specific case of Mexico, Pérez Hurtado (2010) notes a general concern, but little work to reform the provision of legal services has been done.

${ }^{68}$ For example, in Brazil, technically even joint ventures are not allowed. Foreign law firms operate as "legal foreign consultants" (representações e consultoria em direito estrangeiro), which has raised considerable discussion. The Brazilian bar has largely regulated against any formal entry by foreign law firms; see http://www.estadao.com.br/noticias/impresso,o-cerco-aos-escritorios-estrangeiros,691486,0.htm (last checked August 27, 2012).

${ }^{69}$ Consider the case of Argentina. It follows the traditional Spanish model: a law degree is enough to practice law. Until recently, law schools had freedom to choose teaching contents and methods thus generating considerable diversity. Now, there is a national committee (Comisión Nacional de Enseñanza Universitaria) which has to certify the different law degrees. The most immediate implication is a trend to impose uniformity across law schools. At the same time, in 1999, the province of Buenos Aires changed its bylaws to further regulate entry (Ley Reglamentaria de las Profesiones de Procurador y Abogado de la Provincia de Buenos Aires 5177). In Brazil, the low bar passing rates (around ten percent) was not judged by the Supreme Court as a barrier to entry in a unanimous ruling from October 2011; see http://oab-ba.jusbrasil.com.br/noticias/2904715/stf-reconhece-constitucionalidade-do-exame-daoab (checked August 27, 2011). 
Spanish-speaking America has tended to follow the model without bar exam and only bar membership being required for lawyering. This has been challenged on the grounds of not inducing high quality legal professionals. ${ }^{70}$ If successful, ensuing reforms will reregulate legal markets in South America.

Finally, consider the case of Russia. The corporate market is now dominated by Anglo-American law firms. The reason, in part, is the lack of regulation. Lawyering was strictly regulated during the Soviet times. In the 1990s, the Law of the Russia Federation on Entrepreneurial Activity was enacted and foreign law firms used it to enter the Russian legal market and provide legal services, mainly in Moscow. There is no specific licensing, except for court representation in criminal matters (which requires membership of Russian bar). Civil and commercial matters do not require any specific arrangement; foreign lawyers can provide legal advice subject to mere registration. $^{71}$

\section{Globalization and Deregulation}

Globalization and changes in the regulation of lawyering seem to go together. However, the experience around the world shows not always in the same direction. In certain jurisdictions, such as the U.K., major deregulation has followed globalization (in fact, more accurately, we could say that some deregulation proceeded globalization). Jurisdictions such as France and Germany have seen some deregulation imposed by external forces (such as European law) in tandem with court intervention. In other jurisdictions, such as Spain, Portugal or Finland, even in Latin America, reregulation has taken place in response to, or at least at the same time as, globalization. Finally, in many jurisdictions, including the United States and many places in East

\footnotetext{
${ }^{70}$ In fact, in Mexico, there is a trend to reregulate as a response to a general concern about low standards in legal education and practice. A recent report has exposed the problem, http://www.americanbar.org/content/dam/aba/directories/roli/mexico/mexico_legal_profession_reform_index_2011 _en.authcheckdam.pdf (last checked August 27, 2012). Similarly in Colombia, with the Informe Nacional de Competitividad del Consejo Privado de Competitividad en Colombia, 2011-2012, chapter 11. Also in Peru, in Venezuela and in Chile (although the latter has a smaller legal profession within the region) there has been a discussion about this.

${ }^{71}$ There was a short period during 1995-98 when all legal services in Russia required a license.
} 
Asia, little has actually happened. Ribstein believed that such situation in the United States was, by 2010 , unsustainable. His influential work delivered a powerful message: deregulate or perish.

Still, the diversity of responses shows that it is unclear the extent to which the United States will in fact take the deregulation path. The French and German way seems quite unlikely since there is no obvious external force that will push courts to effectively dismantle the current regulatory setup. ${ }^{72}$ Therefore, we are left with the British way (deregulation by statute) or the Spanish way (reregulation and further protection of the incumbents, also by statute). Legal markets are heavily regulated by the state in most jurisdictions. Therefore, deregulation by statute has to be promoted by the government even if, in many jurisdictions, the government is easily captured by local bar interests and therefore hostile to such legal reform.

Ribstein liked explanations based on jurisdictional competition, himself being one of the founding fathers of the theory. ${ }^{73}$ In this context, jurisdictional competition could be driven by lawyers (who presumably want to attract international clients but not effectively open the domestic market), by companies (who want to get the best legal support at the lowest cost) and by legislators (who promote legal regimes depending on their preferences and their goals). Clearly, the pressure for deregulation comes largely from foreign companies and business interests and not from local lawyers wanting to attract foreign business. In fact, as we have seen, the incumbents tend to react by further entrenching themselves rather than embracing regulatory changes. There is not a single example reviewed in this article where deregulation was happily promoted by the local bar.

\footnotetext{
${ }^{72}$ Courts have played important roles in deregulating the market for legal services in the United States in some contexts. For example, the relaxation of rules concerning commercial advertising of legal services was dictated by the Supreme Court of the United States in Bates v. State Bar of Arizona, 433 U.S. 350 (1977). See Johns and Perschbacher (2012), at 55. However, there is no general trend to replicate the impact of EU law in the American context. Certainly the GATS provisions had no such effect. See Young (2003) for detailed discussion.

${ }^{73}$ See O’Hara and Ribstein (2009).
} 
Not surprisingly, Ribstein turned to the English LSA 2007 as the useful mechanism to achieve deregulation or, in the alternative, reform the U.S. regulatory setup. ${ }^{74}$ Yet, within the context of the United Kingdom, the LSA 2007 has hardly mattered for the corporate segment. ${ }^{75}$ The big British and American law firms were already overcoming any regulatory restraints by adjusting their modus operandi well before $2007 .^{76}$ They have been the ones largely benefiting from the European directions on establishment and mutual recognition of qualifications (Directive 2005/36/: $\mathrm{EC}^{77}$ ) and the Treaty of Lisbon and making use of choice of law in international transactions (which tend to be under New York or English law). They were able to enter the more traditional German and French markets under European law. In fact, the big London firms had little need for the LSA 2007 provisions on the new alternative business structures, ABSs. ${ }^{78}$ These law firms had minor demand for outside capital or organizational knowledge. Furthermore, having benefited from European law, they certainly did not want to undermine their German and French partnerships given the extremely negative German reaction to ABSs. In fact, the German reaction to the ABSs allowed by the English LSA 2007 is an illustrative example of how local regulation protects the incumbent legal profession and disadvantages new forms of provision of legal services, a conflict or controversy definitely not welcomed by big law firms. Moreover, at the moment, ABSs, by nature and by market segmentation, are undeniably not a threat to American big law firms in their own domestic market.

At the same time, the impact of ABSs has been significant in the personal segment of the market (personal injury, family, torts, etc.) and welfare law (including employment) which are largely outside the scope of activity of the big law firms. ${ }^{79}$ These are areas of law that are less successful in generating capital (therefore, they benefit more from new sources of capital) and require new

\footnotetext{
${ }^{74}$ Ribstein is not alone in this point. Terry, Mark and Gordon (2012b) argue that the English LSA 2007 introduces regulatory objectives for the legal profession that are consistent with recent developments in Canada, Australia, New Zealand and Ireland. The authors also suggest the U.S. should move in such direction.

${ }^{75}$ See Stephen (2013) for a discussion.

${ }^{76}$ See Stephen (2002) making this point.

${ }^{77}$ Council Directive 2005/36, 2005 O.J. (L 255) 22 (EC).

${ }^{78}$ As explained by Galanter and Roberts (2008) and Stephen (2008).

${ }^{79}$ As recognized and characterized by Stephen (2013).
} 
business models (with a more adequate organizational structure and making the most of economies of scale). ${ }^{80}$

It is clear that most of the insights from Ribstein apply to big law firms, but with a strong focus on the American legal market, for which it is unclear if the English LSA 2007 provides a good benchmark. As suggested by Stephen (2013), the English LSA 2007 might be understood more as a competition framework for different business models in the market for legal services and less so as a new form of shaping self-regulation. ${ }^{81}$

In my view, part of the conceptual problem with Ribstein's analysis and the role of the English LSA 2007 is that globalization in the market for legal services has two different dimensions. The most noticeable dimension is the Americanization of legal practices around the world. In his work, Ribstein convincingly explained this process. U.S. law firms have a production technology advantage in terms of process and management of clients associated with the significant prestige of American legal human capital (including, not least, a long tradition of prestigious LL.M.s ${ }^{82}$ ). We can understand global competition for lawyers (in terms of human capital) as well as for legal technology. One system seems to be superior in technology as well as in human capital formation and stocking. Not surprisingly, such a system has been very successful in the globalization age. Big U.S. law firms have been the main beneficiary, a process slowing down in the last couple of years, as noted by Ribstein, once foreign law firms have achieved a certain threshold in their learning curve.

The second noticeable dimension is the possible conflict between globalization benefiting big law firms and legal isolationism and local parochialism, both in the U.S. and elsewhere. This dichotomy has been much less analyzed. First, local knowledge and local language are important

\footnotetext{
${ }^{80}$ Id.

${ }^{81}$ In the sense of Ogus (1995) as pointed out by Stephen (2013).

${ }^{82}$ See Silver $(2011,2012)$ discussing the value of U.S. LL.M. and J.D. degrees in different foreign countries and the role of foreign legal human capital in the United States.
} 
and difficult to overcome even in the most competitive environment. They are natural barriers to legal business, certainly enhanced in the context of the personal segment. Furthermore, in my view, it is quite unclear the extent to which there is any actual trend for dismantling such barriers. Ribstein himself criticized in Legal Education for the Twenty-First Century the American law school curriculum in terms of having little interest in foreign or comparative law as well as in foreign languages and cultures.

Another particularly important example is the success of the different "law and ..." movements. They are fundamentally American and of little influence elsewhere. In Garoupa and Ulen (2008) and Garoupa (2011), I have explained why this is the case. In particular, the degree of parochialism in legal education, outside of the U.S. as well as within, reflects several realities. ${ }^{83}$ One is the extremely limited influence of American legal scholarship around the world (as compared to, for example, business or economic studies, not to mention hard sciences and technology). Another one is the largely reduced presence of foreign legal scholarship in the American legal academia. Both realities slow down the practical effects of globalization and inevitably undermine many of the brilliant suggestions in Legal Education for the Twenty-First Century. They artificially enhance barriers that cannot be easily changed and presumably are time persistent.

\section{Conclusions}

As noted by Ribstein, changes in technology have allowed law firms to shift some legal services, primarily in the commodity end of legal work, to foreign jurisdictions with cheaper labor costs. However, "this" globalization has hardly induced any significant competition or deregulation. The personal segment of the market is largely local and untouched by globalization in almost every jurisdiction we have discussed in this article. Moreover, in a reaction to global competition in the corporate segment, local law firms pressure for reregulation in the personal segment.

The corporate segment of the market is dominated by large law firms that can easily bypass strict regulation and, at the same time, deter entry by foreign law firms. For a while, Anglo-American

\footnotetext{
${ }^{83}$ See also Larouche (2012) on global legal scholarship.
} 
law firms have benefited from a better technology but lacked local knowledge. A better technology is easy to copy (since Anglo-American law firms have no property right over templates and legal practices) but local knowledge is difficult to acquire. Inevitably local big law firms have acquired the Anglo-American technology while the Anglo-American law firms have not significantly improved their local knowledge (not least, because legal education is largely parochial). As a consequence, I do not share the view that foreign markets are a significant alternative to domestic markets for Anglo-American law firms as suggested by Ribstein. My prediction is that their market share will actually go down in the future. At the same time, the pressure for deregulation is largely absent at the moment. In that sense, the U.S. is no exception.

The U.S. situation of big law firms discussed by Ribstein is largely U.S.-specific and cannot be easily generalized. Therefore, one should be much less optimistic about using globalization to help U.S. lawyering. For example, although sharing many of the proposals in Legal Education for the Twenty-First Century, I do not see how Ribstein's insights can be practically combined with a persistent parochialism in legal education and thinking.

We have reviewed many different paths taken by a diversity of jurisdictions in response to globalization. Ribstein was particularly influenced by the English LSA 2007. We have seen that the U.K. has largely been an exception. At the same time, we have argued that the LSA 2007 does not seem to be the answer to the structural shortcomings of the big law firms identified by Ribstein. In our view, the result is that the relationship between globalization and deregulation is much more nuanced and probably more problematic than suggested by Ribstein.

Around the world, the main consequence of the globalization of the market for legal services has been the segmentation between corporate and personal services rather than deregulation. We have argued that segmentation, in fact and paradoxically, reduces the pressure for deregulation. The corporate segment is largely a creation of globalization. This has generated more competition and most probably cost-effective corporate legal services around the world. However, these significant changes have not induced the kind of deregulation that legal economists think important for the adequate provision of legal services. 
The corporate-personal market segmentation is inevitably endogenous to the technology. Therefore, significant innovations caused by current globalization of corporate legal services might change future segmentation patterns. If so, we can easily understand reregulation trends as a sophisticated strategy to undermine those kinds of innovation or to avoid blurring the line between segments (for example, internet legal services that are now explicitly prohibited by recent bylaws in many jurisdictions). 


\section{REFERENCES:}

Richard L. Abel, English Lawyers between Market and State. The Politics of Professionalism, Oxford Socio-Legal Studies, Oxford: Oxford University Press (2003).

Soledad Atienza, The Evolution of Legal Education in Spain, 61 Journal of Legal Education, 468-478 (2012).

Swethaa Ballakrishen, Homeward Bound: What does a Global Legal Education offer the Indian Returnees, 80 Fordham Law Review 2441-2480 (2012).

Andrew Boon, Professionalism under the Legal Services Act 2007, 17 International Journal of the Legal Profession 195-232 (2011).

Roger A. Bowles, The Structure of the Legal Profession in the UK, 10 Oxford Review of Economic Policy 18-33 (1994).

Jutta Brunnee, The Reform of Legal Education in Germany: The Never-Ending Story and European Integration, 42 Journal of Legal Education 399 (1992).

Kuan-Chun Chang, The Teaching of Law in the United States: Studies on the Case and Socratic Methods in Comparison with Traditional Taiwanese Pedagogy, 4 National Taiwan University Law Review 1-40 (2009).

Thomas Chih-hsiung Chen, Legal Education Reform in Taiwan: Are Japan and Korea the Models?, 62 Journal of Legal Education 32-65 (2012).

Sir David Clementi, Review of the Regulatory Framework for Legal Services in England and Wales, London: Department of Constitutional Affairs (2004). 
Mark Cohen, International Law Firms in China: Market Access and Ethical Risks, 80 Fordham Law Review 2569-2575 (2012).

Lovely Dasgupta, Reforming Indian Legal Education: Linking Research and Teaching, 59 Journal of Legal Education 432-449 (2010).

Yves Dezalay and Bryant G. Garth, The Internationalization of Global Palace War: Lawyers, Economist, and the Contest to Transform Latin American States, Chicago: University of Chicago Press (2002).

Yves Dezalay and Bryant G. Garth, Asian Legal Revivals: Lawyers in the Shadow of Empire, Chicago: University of Chicago Press (2010).

Marc Galanter and Simon Roberts, From Kinship to Magic Circle: The London Commercial Law Firm in the Twentieth Century, 15 International Journal of the Legal Profession 143-178 (2008).

Nuno Garoupa, Providing a Legal Framework for the Reform of the Legal Profession: Insights from the European Experience, 9 European Business Organization Law Review 463-495 (2008).

Nuno Garoupa, The Law and Economics of Legal Parochialism, University of Illinois Law Review 101-113 (2011).

Nuno Garoupa and Thomas S. Ulen, The Market for Legal Innovation: Law and Economics in Europe and in the United States, 59 Alabama Law Review 1555-1633 (2008).

Tom Ginsburg and Glenn Hoetker, The Unreluctant Litigant? An Empirical Analysis of Japan's Turn to Litigation, 35 Journal of Legal Studies 31-59 (2006).

Tom Ginsburg and Glenn Hoetker, Liberalization and Litigation: Evidence from Japan, 8 Washington University Global Studies Law Review 303-315 (2009). 
Gillian K. Hadfield, The Price of Law: How the Market for Lawyers Distorts the Justice System, 98 Michigan Law Review 953-1006 (2000).

Gillian K. Hadfield, Legal Barriers to Innovation: The Growing Economic Cost of Professional Control over Corporate Legal Markets, 60 Stanford Law Review 1689-1732 (2008).

Gail J. Hupper, The Academic Doctorate in Law: A Vehicle for Legal Transplants, 58 Journal of Legal Education 413-454 (2008).

Young-Cheol K. Jeong, Korean Legal Education for the Age of Professionalism: Suggestions for More Concerted Curricula, 5 East Asia Law Review 155-196 (2010).

Margaret Z. Johns and Rex R. Perschbacher, The United States Legal System: An Introduction, Durham: Carolina Academic Press (2012).

Eckart Klein, Legal Education in Germany, 72 Oregon Law Review 953 (1993).

Pierre Larouche, A Vision of Global Legal Scholarship, TILEC Discussion-Paper 2012-034 (2012), http://papers.ssrn.com/sol3/papers.cfm?abstract_id=2158638

Xueyao Li and Sida Liu, The Learning Process of Globalization: How Chinese Law Firms Survived the Financial Crisis, 80 Fordham Law Review 2847-2866 (2012).

Julian Lonbay, The Changing Regulatory Environment Affecting the Education and Training of Europe's Lawyers, 61 Journal of Legal Education 479-485 (2012).

James R. Maxeiner and Keiichi Yamanaka, The New Japanese Law Schools: Putting the Professional Into Legal Education, 13 Pacific Rim Law and Policy Journal 303-328 (2004).

Shigenori Matsui, Turbulence Ahead: The Future of Law Schools in Japan, 62 Journal of Legal Education 3-31 (2012). 
Ethan Michelson, Access to Lawyers: A Comparative Analysis of the Supply of Lawyers in China and the United States, 7 National Taiwan University Law Review 223- 255 (2012).

Juny Montoya, The Current State of Legal Education Reform in Latin America: A Critical Appraisal, 59 Journal of Legal Education 545-566 (2010).

Anthony Ogus, Rethinking Self-Regulation, 15 Oxford Journal of Legal Studies 97-108 (1995).

Erin O'Hara and Larry Ribstein, The Law Market, Oxford: Oxford University Press (2009).

Juergen Ostertag, Legal Education in Germany and the United States - A Structural Comparison, 26 Vanderbilt Journal of Transnational Law 301 (1993).

Luis Fernando Pérez Hurtado, Content, Structure, and Growth of Mexican Legal Education, 59 Journal of Legal Education 567-597 (2010).

Neil J. Philipsen, Regulation and Competition in the Legal Profession: Developments in the EU and China, 6 Journal of Competition Law and Economics 203-231 (2010).

Ashly H. Pinnington and John T. Gray, The Global Restructuring of Legal Services Work? A Study of the Internationalisation of Australian Law Firms, 14 International Journal of the Legal Profession 147-172 (2007).

Mark Ramseyer, Law and Economics in Japan, University of Illinois Law Review 1455-1474 (2011).

Larry E. Ribstein, Ethical Rules, Agency Costs and Law Firm Structure, 84 Virginia Law Review 1707-1759 (1998). 
Larry E. Ribstein, Lawyers as Lawmakers: A Theory of Lawyer Licensing, 69 Missouri Law Review 299-364 (2004).

Larry E. Ribstein, The Death of Big Law, Wisconsin Law Review 749-815 (2010).

Larry E. Ribstein, Practicing Theory: Legal Education for the Twenty-First Century, 96 Iowa Law Review 1649-1676 (2011).

Annelise Riles and Takashi Uchida, Reforming Knowledge? A Socio-Legal Critique of the Legal Education Reforms in Japan, 1 Drexel Law Review 3-51 (2009).

Charunun Sathitsuksomboon, Thailand's Legal System: Requirements, Practice, and Ethical Conduct, available here http://www.thailawforum.com/articles/charununlegal2.html (last checked August 27, 2012).

George Schumann, Beyond Litigation: Legal Education Reform in Japan and What Japan's New Lawyers Will Do, 13 University of Miami International and Comparative Law Review 475-526 (2006).

Adam Sechooler, Globalization, Inequality, and the Legal Services Industry, 15 International Journal of the Legal Profession 231-248 (2009).

Carole Silver, The Variable Value of U.S. Legal Education in the Global Legal Services Market, 24 Georgetown Journal of Legal Ethics 1-58 (2011).

Carole Silver, States Side Story: Career Paths of International LL.M. Students, or "I Like to be in America," 80 Fordham Law Review 2383- 2440 (2012).

Frank H. Stephen, The European Single Market and the Regulation of the Legal Profession: An Economic Analysis, 23 Managerial and Decision Economics 115-125 (2002). 
Frank H. Stephen, Regulation of the Legal Professions or Regulation of Markets for Legal Services: Potential Implications of Legal Services Act 2007, 19 European Business Law Review 1129-1139 (2008).

Frank H. Stephen, Lawyers, Markets and Regulation, London: Edward Elgar Publishers (2013).

Laurel S. Terry, U.S. Legal Ethics: The Coming of Age of Global and Comparative Perspectives, 4 Washington University Global Studies Law Review 463-533 (2005).

Laurel S. Terry, The European Commission Project Regarding Competition in Professional Services, 29 Northwestern Journal of International Law and Business 1-118 (2009).

Laurel S. Terry, Steve Mark, and Tahlia Gordon, Trends and Challenges in Lawyer Regulation: The Impact of Globalization and Technology, 80 Fordham Law Review 2661-2684 (2012a).

Laurel S. Terry, Steve Mark and Tahlia Gordon, Adopting Regulatory Objectives for the Legal Profession, 80 Fordham Law Review 2685-2760 (2012b).

Stewart M. Young, Whistleblowing in a Foreign Key: The Consistency of Ethics Regulation Under Sarbanes-Oxley with the WTO GATS Provisions, 32 Denver Journal of International Law and Policy 55-81 (2003).

Eli Wald, Smart Growth: The Large Law Firm in the Twenty-First Century, 80 Fordham Law Review 2867-2915 (2012).

Hariolf Wenzler and Kasia Kwietniewska, Educating the Global Lawyer: The German Experience, 61 Journal of Legal Education $462-467$ (2012).

Jun Zhao and Ming Hu. A Comparative Study of the Legal Education System in the United States and China and the Reform of Legal Education in China, 35 Suffolk Transnational Law Review 329-361 (2012). 
